doi: 10.52370/TISC21111BM

\title{
DIGITAL MARKETING OF AGRI-FOOD PRODUCTS IN SUPPORT OF RURAL TOURISM DURING THE COVID PANDEMIC
}

\author{
Branko Mihailovićl $^{\text {; Vesna Popovic }}{ }^{2}$
}

\begin{abstract}
The paper explores the possibilities of restructuring the activities of rural tourism in Serbia, during the COVID pandemic. Having in mind the shock experienced by the tourism sector, as well as the area of rural tourism, digital marketing of agricultural and food products is imposed as one of the solutions. Namely, through online platforms and modern logistics, producers can consolidate business revenues during a pandemic, when rural tourism is almost impossible. The move can be seen as a short-term business restructuring caused by a pandemic. In that way, with the measures of state support, the area of rural tourism in Serbia can be preserved, in order to be ready for the period after the pandemic. Digitization enables small agricultural producers to survive and strengthen their market position in conditions of intensified global competition. This is achieved through digital cooperation, which can play the role of one large agricultural producer, thus achieving the effects of economies of scale, size and breadth.
\end{abstract}

Key Words: digital marketing, agri-food products, online platforms, tourism, rural tourism.

JEL classification: M31, L83, O18, R51

\section{Introduction}

International and European tourism have seen constant and almost unprecedented growth over the last decades (Ardeljan et al., 2020, p. 93).

1 Branko Mihailović, Ph.D., Senior Research Associate, Institute of Agricultural Economics, Volgina Street no. 15, 11060 Belgrade, Serbia, 0116972858, brankomih@neobee.net

${ }^{2}$ Popović Vesna, Ph.D., Scientific Adviser, Institute of Agricultural Economics, Volgina Street no. 15, 11060 Belgrade, Serbia, 0116972858, vesna_p@iep.bg.ac.rs 
In 2018, a turning point was reached when international tourism recorded its ninth consecutive year of growth, exceeding even world GDP in terms of growth, according to the United Nations World Tourism Organization (UNWTO).. The beginning of 2020 brought the spread of the global pandemic, and the tourism and travel industry proved to be one of the most sensitive industries (Ardeljan et al., 2020, p. 93). From this point of view, a pandemic is an opportunity to rethink the criteria for ensuring sustainable tourism, while at the same time proving the fragility of the entire tourism sector (Ardeljan et al., 2020, p. 93).

Rural tourism allows consumers to return to the natural environment and relieve the pressure and stress that arises in urban areas. As an ecological journey to relatively preserved areas, rural tourism is an important element of sustainable tourism, economic and social development of rural areas (Grubor et al., 2019). Rural tourism with its specifics requires a careful approach to tourist demand and its segments, or niches. Consistent application of the marketing concept with adequate investments in market research, creation and marketing of a tourist product is a guarantee of success (Vuković, 2018, p. 81). On the other hand, "it is important to define the possibilities for the development of certain forms of rural tourism on the basis of territorial capital" (Rokvić-Knežić et al., 2020, p. 35).

Successful marketing of rural tourism requires knowledge of consumer behavior. First of all, they have to answer the question which consumer profile corresponds to a certain tourist destination (Tomić et al., 2020). Research indicates a high assessment of the perception of service quality in rural tourism in the Republic of Serbia (Perić et al., 2020, p. 1). At the same time, special attention should be paid to the presentation of local resources that are suitable for the development of food tourism (Vuković et al., 2020, p. 77). Food is certainly one of the very important elements on any trip. Most tourists on the trip want to try something new and unusual. Authentic food is in part a representation of a nation as well as a region (Janković et al., 2020, p. 81). Namely, he considers the hedonistic culinary experience to be an unmistakable element of authentic travel experiences $(91.4 \%)$, and that adequate marketing of very tasty food contributes the most to the development of tourist destinations (Vujko et al., 2020, p. 1). Food tourism is a topic of increasing interest in relation to its potential contribution to regional development (Mihailović et al., 2020, p. 2). 


\section{Impact of COVID-19 on the tourism sector}

Given the specificity of the new situation, at the moment, the epidemic phase varies greatly from country to country, and the policies adopted by decision makers are very specific, reflecting the economic and health context in which each country finds itself. "While the medium- and longterm impacts of COVID-19 remain uncertain and will vary from country to country and industry segment, governments often take aggressive and coordinated action locally, nationally, and internationally to reduce business losses and closures. but also in the long run" (Research Center of the Parliament of Montenegro, p. 6).

The economic impact varies in the branches of the tourism industry depending on a number of factors, including the nature of the tourist offer, the impact of travel restrictions on the flow of visitors, the volume and complexity of business, the size of the domestic tourism market and exposure to international markets, has an obvious connection with small and medium enterprises, as most enterprises in the tourism sector are smallscale (Research Center of the Parliament of Montenegro, p. 8).

Costs related to the prevention of the spread of viruses and changes in the work process (where this is feasible in the context of tourism), such as the introduction of telework, may be relatively higher for small and mediumsized enterprises (Organisation for Economic Co-operation and Development - OECD, 2020, p. 8).

"With international air traffic interrupted, the closure of major tourist sites and attractions canceling or postponing major festivals and events, and the banning of public gatherings (closed and open) in many countries, the impact of COVID-19 on global tourism is huge and immediate" (OECD, 2020 , p. 11). Countries have shut down the economy to slow the spread of the coronavirus. Supermarket shelves remain stocked for now. But a protracted pandemic crisis could quickly put a strain on the food supply chains, a complex web of interactions involving farmers, agricultural inputs, processing plants, shipping, retailers and more (Cullen, 2020, p. 1). An important role in the improvement of rural tourism in Serbia could play a small business (Mihailović \& Popović, 2019, pp. 251-266).

The three main categories of potential responses to the crisis in the tourism sector are the following (OECD, 2020): 
1. Protection of people - protection of visitors (information, support for returning home, protection of consumers) and tourist workers (such as providing a guaranteed income);

2. Ensuring the survival of the business - along the entire supply chain in the field of tourism;

3. Establish coordination mechanisms - including working groups and measures for better targeted action and recovery of the sector.

\section{Marketing aspects of rural tourism}

"Tourism has become an important economic branch of a large number of countries in the world, and in some it has become the leading one" (Cvijanović, Mihailović, 2016, p. 2). This is evidenced by the income they earn from tourism. Having in mind such tendencies, the European Union promoted the multifunctional concept of development in its program of the common agricultural policy, better known under the acronym CAP (Common Agricultural Policy), which envisages tourism as one of the development perspectives. Namely, the common agricultural policy of the European Union must be directed as an integrated policy that contributes to other elements of social policy, primarily in the direction of rural development (Cvijanović et al, 2011, p. 62).

In this context, as the predominant tendencies on the side of tourist demand, especially in Europe, we can single out (Cvijanović, 2014, p. 132):

- refreshment through contrast (tourist trips on the route lowlandsmountains, town-village, mainland-island, etc.),

- striving for experiences related to cultural and historical heritage and preserved nature, "green" movement or tourism, which is also called alternative, responsible, "soft", "good" or "new" tourism - refers to rural tourism, so also in the cities, and on the coast. It means, above all, clean water, clean and safe sea, healthy food and unpolluted air, ie tourism that is not massive but "friendly" directed towards the natural environment,

- "blue" or nautical movement, ie demand, (sea cruise using marina, port and anchorage systems),

- demand for places, events and experiences that have a strong identity, integrity and diversity,

- demand for rural (agritourism) and agritourism - means staying in different types of accommodation (not exclusively in rural households) and engaging in activities (sports, adventure, challenges, art, handicrafts, etc.), 
- demand for health, spiritual, mental renewal and renewal of identity refers to new forms of health or spa tourism: striving for better fitness (recreational activities, sports and exercises, diet, fitness) and the desire for better health through the fight against stress.

The structure of employment and income of the rural population indicates that Serbia is dominated by "distressed" income diversification resulting from the unfavorable economic environment and poverty. At the same time, the largest share in the total income of the rural population of all areas has the salaries of employees, followed by the salaries of agriculture. The economic development of rural areas implies a much wider area than agriculture, and the goals of rural development policy and measures do not refer exclusively to farms and producers.

According to Article 12 of the Law on Agriculture and Rural Development: "rural development measures are a type of incentive that encourages the improvement of competitiveness in agriculture and forestry (investment in agriculture and forestry and the introduction of new standards in production and trade of agricultural products), improvement of environmental protection programs, preservation of biodiversity and programs for diversification of the rural economy and improvement of the quality of life in rural areas" (Law on Agriculture and Rural Development, No. 41/09).

Considering the characteristics of rural regions in Serbia, the dominant causes of their slow development are: unfavorable impact of the pandemic, migration of rural population to urban areas, unfavorable age structure, insufficient investment in rural areas, identification of agriculture with rural development with insufficient engagement in non-agricultural activities (Cvijanović et al., 2012, 7-25).

Through online platforms and modern logistics, producers can consolidate business revenues during a pandemic, when rural tourism is almost impossible. The move can be seen as a short-term business restructuring caused by a pandemic. In that way, with the measures of state support, the area of rural tourism in Serbia can be preserved, in order to be ready for the period after the pandemic. 


\section{Digital marketing in agribusiness}

"The development of e-commerce of agricultural products has a 40-year history, it experienced the primary e-commerce affairs from twentieth century 70's used telephone as communication tools, conduct e-commerce trade from 90's used computer online and finally used satellite technology, Internet etc since twenty-first century, which is the highest stage of the development of e-commerce" (Yiqing \& Lijuan, 2015, p. 561).

It has been indicated that the adoption and development of e-commerce is an innovative way of influencing food systems and market access for smallholders (Zenga et al., 2017, p. 455). "Short supply food chains cover a wide range of direct sale arrangements (on-farm selling, pick your-own, farmers' markets, sale booths, box schemes and direct online selling) as well as indirect relations with one or very few intermediaries (restaurants, neighbouring farm' shops, local supermarkets purchasing food directly from nearby farmers, collective point of sale, etc.)" (Popović \& Mihailović, 2020, p. 100).

"Application of computer reservation systems (CRS) and global distribution systems (GDS) completely changes the role that intermediaries (travel agencies/tour operators) have until recently" (Vuković et al., 2016, p. 257). "The research results show that a higher level of quality of internet content has a positive effect on tourists choosing a certain destination of cultural tourism for travel and that internet content in terms of information efficiency, interactivity and practicality has a significant positive impact on tourists' intentions to visit cultural tourism destination" (Dramićanin \& Sančanin, 2020, p. 1).

Direct marketing has three essential components: direct propaganda economic propaganda, a developed and efficient data bank, direct building of relationships with consumers to increase sales volume, market share and profit. Unlike mass marketing, which identifies consumers as a group that has common demographic characteristics, direct marketing identifies consumers by name, address, and shopping behavior. Direct marketing in production and sales can be achieved through: 1) maximarketing, 2) database marketing, 3) telemarketing and 4) interactive marketing (Cvijanović et al., 2009).

Maximarketing is the use of a consumer data bank and economic propaganda in the function of creating a targeted message that contributes 
to the creation and expansion of permanent relationships with a specific group of consumers. Database marketing includes an extensive list of relevant information for a narrow target group of very promising consumers with an offer of companies of interest to them. Telemarketing, as the name suggests, is selling over the phone. The last form of direct marketing, the so-called. interactive marketing implies a system of media that allows companies and individuals as consumers to participate in twoway communication through computers, television, fax (Cvijanović et al., 2009). The successor of the industrial revolution - the information economy and the virtual Internet space - are successfully penetrating all aspects of everyday life, economy and trade, changing the current practice and norms. The digital revolution and computer technology are fundamentally changing the notion of space, time and matter. Namely, the company no longer has to take up much space, it can be virtual and located anywhere. Businesses can be connected to each other and to customers in a seamless virtual network. Finally, the importance and role of e-commerce ("online" or online trade), in relation to retail channels, is growing.

In the developed countries of the market economy, the Internet has already entered the field of agriculture, and the spectrum of application of the Internet for all marketing is very wide: from online propaganda, through online shopping (or sales), to online services. The company can use the Internet to research the environment and the market, to provide information (creating its own website), participate in discussions, perform direct Internet purchases and sales, exchanges, auctions, etc. Namely, you can always find the latest local weather forecast on the Internet, but you can also buy seeds or fertilizer or sell the final product via a worldwide computer network. The number of farmers running their own websites in the Netherlands (the situation in the Netherlands is a mirror of the general direction throughout the European Union) is increasing rapidly. It is interesting to note that in the world, it is the new generation of farmers young, educated, and ambitious - who use Net technology to increase productivity and profits.

Farmers see the meaning of using online marketing, ie the Internet in agriculture, in the speed and ease of access to numerous information, as well as in the possibilities to perform business transactions (purchases and sales) without intermediaries and from "their backyard". Young farmers today do not have enough time and want to use all the opportunities available to them and all the tools available to them - software, Internet, satellites, robotics (eg for milking), biotechnology - to do much more in 
less time. The ranges of computer technology in agriculture are interesting, although they are used and applied by a small number of farmers and in developed countries. For example, through a transmitter, ie a small device - a radio transmitter (which is tied around the right link on each head of cattle), the farmer can monitor the condition of each cow on the farm on graphs of a computer system, eg fertilization times). Although expensive (about $\$ 70,000$ ), this software solution successfully replaces a key person on the farm (Cvijanović et al., 2009). Also, farmers today are able to enjoy the benefits of milking robots, as well as to use remote solar irrigation systems, which they control via central computers (Cvijanović et al., 2009).

In that sense, Internet exchanges like Farmbid allow farmers to order and sell 24 hours a day and exchange orders in real time, without wasting valuable time from the working day to contacts with local dealers, to purchase input or sell their products. This greatly changes the position of producers, who are almost completely excluded from money transactions related to trade in their products. One of the problems of modern technology is that it allows large farmers to become even bigger, but that same technology increases competition among small producers. One of the sites of the Internet exchange - Farmbid, however, allows small farmers to survive in the market, by being able to unite and create a "virtual cooperation", which will play the role of one large producer. The digital revolution has opened the door for newly started companies, which are implementing a niche strategy, to enter the world market with a small amount of capital. For example, the wine company Clos LaChance started a business as a virtual vineyard. Namely, the owner buys grapes from other vineyards, rents space for production and storage, finds people talented in making wine, labels, bottles and stoppers and sells only over the Internet. As a virtual company, it strives to compete with Mondavi and other, financially well-off and organized, wine producers. Finally, today there are many websites that deal with agribusiness and many companies are trying to become a link between producers, distributors and customers in one place by creating Internet sites.

\section{Digital marketing of agri-food products: development potential of Braničevo Podunavlje (BP) region}

Having in mind the shock experienced by the tourism sector, as well as the area of rural tourism, digital marketing of agricultural and food products is imposed as one of the solutions. By producing competitive agri-food products, agriculture in the BP region would ensure sufficient income for 
agricultural holdings, focusing its activities on meeting the needs and preferences of consumers and working closely with the food processing industry (Mihailović, Radić-Jean, 2019, 678). "In order to achieve this, certain economic, social and environmental goals must be fulfilled: 1 . agriculture must efficiently use natural resources, 2 . it must be integrated into the rest of the rural economy and society 3. it must significantly contribute to environmental protection" (Radić-Jean \& Mihailović, 2019, 41). Since there is a certain correlation between financial and marketing performance (PIMS model), it is useful to determine which marketing activities are undertaken by the surveyed producers in the BP region. The survey showed (Figure 1) that the most common marketing activities are: mouth-to-mouth promotion (28\%) and participation in fairs $(25.71 \%)$ (Mihailović et al., 2020, 9).

Figure 1: Marketing activities

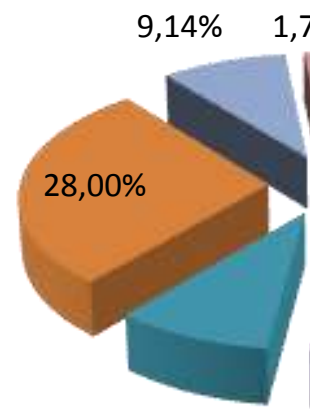

$9,14 \%$

\section{$1,71 \%$}

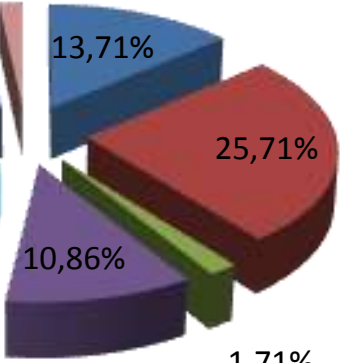

creating and protecting the brand

participation in fairs

cooperation with marketing agencies

advertising

organizing tasting

- "from mouth to mouth"

Source: Regional Development Agency Braničevo-Podunavlje (RDA-BP), 2019

At the same time, the construction and protection of the brand is present in $13.71 \%$ of the surveyed producers. It is positively surprising that only $1.71 \%$ of the surveyed producers do not deal with marketing, which indicates that in the BP region there is a certain affirmative awareness of the importance of marketing activities (Mihailović et al., 2020,9). 
"Information and communications technologies are playing an increasingly important role in keeping farmers and rural entrepreneurs informed about agricultural innovations, weather conditions, input availability, financial services and market prices, and connecting them with buyers" (FAO, 2017, p. 54).

When asked: Are you using modern IT technologies for marketing and promotion of your product, the following answers have been received (Mihailović et al., 2020, 10):

1. I have a website for an agricultural holding or a product: $27.78 \%$;

2. I have a Facebook page for an agricultural holding or a product: $41.11 \%$;

3. I have an Instagram site for an agricultural holding or product: $13.33 \%$;

4. I do not use modern IT technologies for marketing and promotion: $17.78 \%$.

The majority are those producers $(47.11 \%)$ who have a Facebook page for an agricultural holding or product, which is understandable as it is a free advertising medium (Figure 2) (Mihailović, Radić-Jean, p. 29).

Figure 2: Use of modern IT technology for marketing and promotion of products

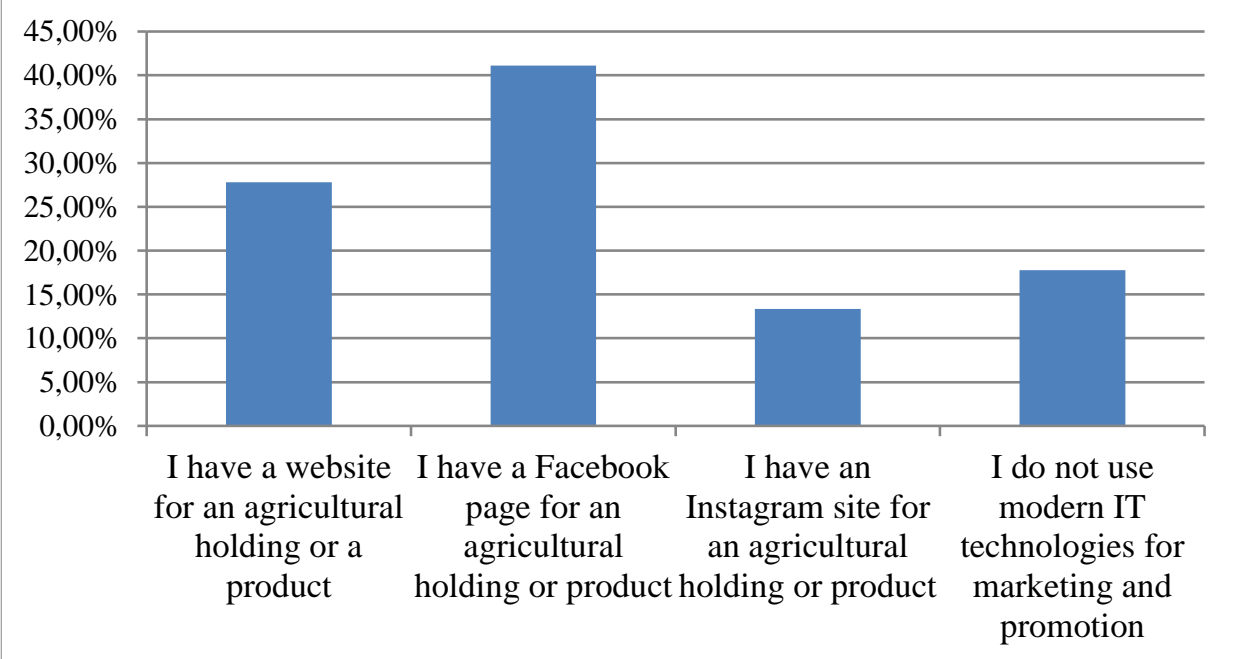

Source: Regional Development Agency Braničevo-Podunavlje (RDA-BP), 2019

At the same time, almost $18 \%$ of surveyed producers do not use modern IT technologies for marketing and promotion, which increases the need for 
training and education of manufacturers in this field (Mihailović, RadićJean, p. 29).

Existing products are dominantly oriented to the domestic market (73.1\%), and the remaining $26.9 \%$ of the producers are selling products on both domestic and foreign markets (Figure 3) (Mihailović et al., 2020, 10). It is interesting that no surveyed producer places products exclusively on foreign markets.

Figure 3: Sales channel structure

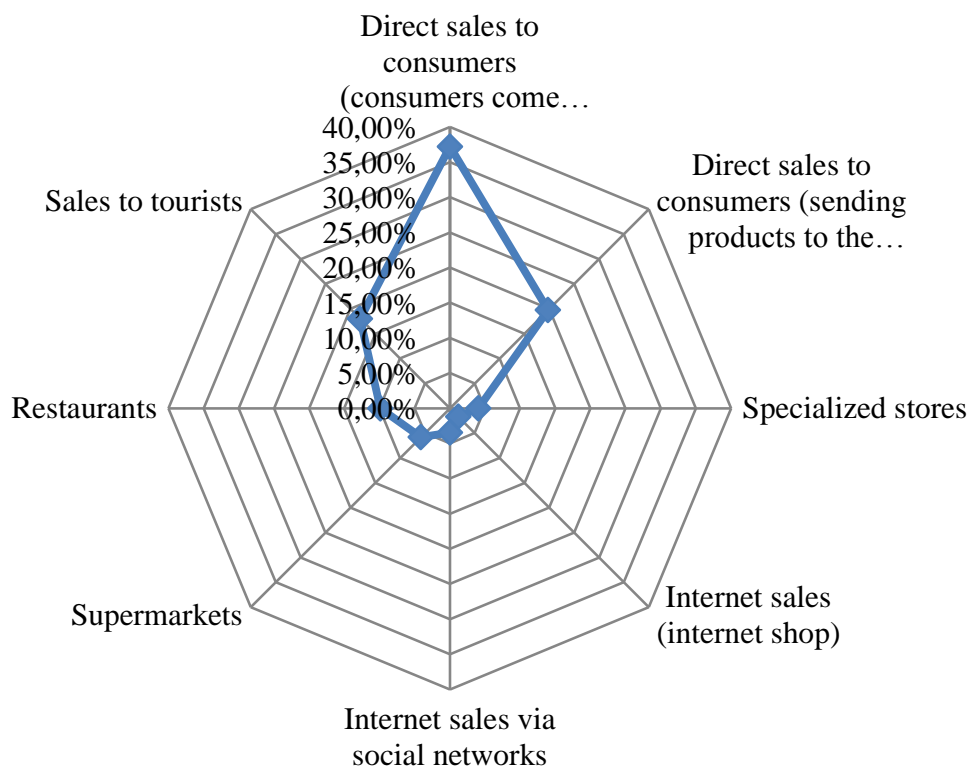

Source: Regional Development Agency Braničevo-Podunavlje (RDA-BP), 2019

Analysis of the sales channel structure indicates that agricultural products in the BP region are mainly sold directly to consumers:

a) consumers come to the manufacturer $(37.21 \%)$;

b) products are sent to the address $(19.77 \%)$ (Mihailović et al., 2020, 10).

Sales to tourists as a sales channel are used in $18.02 \%$ of producers and have a certain significance for the development of the BP region due to linking tourism and agri-food products of this region. There is relatively 
little sales channel participation through specialized stores, social networks and online stores (Mihailović et al., 2020).

\section{Digital platform for the sale of agri-food products: Local market}

"At present, the developed countries due to the popularity of e-commerce and information technology in agriculture, have rapid development of ecommerce of agricultural products" (Yiqing \& Lijuan, 2015, 561). Digitization enables small agricultural producers to survive and strengthen their market position in conditions of intensified global competition. This is achieved through digital cooperation, which can play the role of one large agricultural producer, thus achieving the effects of economies of scale, size and breadth. Local Market (Lokalni za Pazar, 2019) is a regional, multisectoral initiative to support producers of food and beverages and other agricultural products in the Braničevo-Podunavlje region. The aim of the initiative is to encourage the purchase of local products, through free advertising of producers on the Internet portal, or intensive promotional campaigns on the Internet, social networks and local media, which will inform and animate residents to contact producers and reach the desired products (Lokalni za Pazar, 2019). In the environment of the epidemic caused by the spread of coronavirus and the consequent measures that disrupted the daily life of each individual and society as a whole, more than ever we are directed at each other, our family, neighbors, acquaintances. In order to overcome this period together as successfully as possible, it is necessary to turn to other ways of thinking and functioning (Lokalni za Pazar, 2019).

The initiative encourages connecting customers with food and beverage producers in their local communities through a simple service called Local Market, which will allow an easy search of product offerings in the neighborhood, contacting old and new producers of cheese, seedlings or fresh vegetables and agreement on downloading the desired products (Lokalni za Pazar, 2019).

\section{Conclusion}

The information economy and digitalization are spreading like "circles in water" to almost all sectors of the economy, as well as aspects of everyday life. The current practice and business rules are changing radically. The IT and digital revolution has significantly changed our understanding of the world around us. Digitization enables small farmers to survive and 
strengthen their market position in the conditions of COVID-19. This is achieved through digital cooperation, which can play the role of a large agricultural producer, thus achieving the effects of economies of scale, size and breadth. Also, the decline in income in rural tourism can be compensated, primarily through online sales of agri-food products. Thus, digitalization can be understood as a form of business restructuring, which is the initial capsule for financial restructuring.

Accordingly, "Digital Platforms" for the sale of agri-food products represent a link between producers, distributors and customers in one place, with complete consumer satisfaction being the primary goal. Consequently, due to COVID-19, the importance of online trade has increased compared to traditional retail channels.

\section{Acknowledgements}

Realization of research financed from the budget of the Republic of Serbia, based on the Decision of the Ministry of Education, Science and Technological Development on financing scientific research work in 2021, number: 451-03-9 / 2021-14.

\section{References}

1. Ardeljan, P., Cismaș, L. M., Medić, V. (2020). COVID-19 - prilika ili pretnja evropskom turizmu. TIMS. Acta, Vol. 14, No.2, 93-101.

2. Cullen, M.T. (2020). COVID-19 and the risk to food supply chains: How to respond, http://www.fao.org/3/ca8388en/CA8388EN.pdf, (12 February 2021).

3. Cvijanović, D., Mihailović, B., Paraušić, V., (2012): The rural development policy of EUin contextof improving ruralareas of Serbia, Thematic proceedings "Rural areas and development", vol. 9, Publishers: ERDN: European Rural Development Network; Institute of Agricultural and Food Economics, Warsaw, Poland; Institute of Agricultural Economics Belgrade, pp. 7-25.

4. Cvijanović, D. (2014). Turističko tržište u dunavskom regionu, Institut za ekonomiku poljoprivrede, Beograd. 
5. Cvijanović, D., Mihailović, B., Simonović, Z. (2009). Uloga i značaj marketinga u razvoju agrarnog sektora Srbije, Institut za ekonomiku poljoprivrede, Beograd.

6. Cvijanović, D., Mihailović, B., Vukotić, S. (2016). Marketing $i$ konsalting u funkciji razvoja turizma Srbije, Institut za ekonomiku poljoprivrede, Beograd.

7. Cvijanović, D., Mihailović, B. (2016). "Developmental aspects of the Rural Tourism in Serbia", Zbornik radova sa međunarodne konferencije: "Tourism in function of development of the Republic of Serbia - Spa Tourism in serbia and Experiences of Other Countries", Thematic Proceedings II, Organizator: University of Kragujevac, Faculty of Hotel Management abd Tourism in Vrnjačka Banja, Vrnjačaka Banja, 2-4 June, 2016; 1-16.

8. Cvijanović, D., Simonović, Z., Mihailović, B. (2011). The Commnon Agricultural Policy in the function of organic production development in EU. European Union Food Sector after the last enlargements - conslusion for the future CAP, Multi-annual programme: Competitiveness of the Polish food economy under the conditions of globalization and European intergration, No. 6.1 (pp. 62-79). Institute of Agricultural and Food Economics - National Research Institute, Warsaw, Poland.

9. Dramićanin, S., Sančanin, B. (2020). Uticaj internet sadržaja na odluku turiste o poseti destinacije kulturnog turizma. Bizinfo (Blace), Vol. 11, No. 2, 1-17.

10. Food and Agriculture Organization of the United Nations - FAO, (2017), The future of food and agriculture - Trends and challenges, http://www.fao.org/3/i6583e/i6583e.pdf, (01 February 2021).

11. Grubor, A., Leković, K., Tomić, S. (2019). Marketing ruralnog turizma Dunavskog regiona. Ekonomika, Vol. 65, No. 4, 1-9.

12. Janković, I., Ćirić, M., Vujasinović, V. (2020). Uticaj autentične hrane na odabir turističke destinacije. Bizinfo (Blace), Vol. 11, No. 2, 81-92.

13. Law on Agriculture and Rural Development, Official Gazette of RS, No. 41/09. 
14. Lokalni za Pazar, (2019), https://www.lokalnipazar.rs/o-inicijativi, (05 April 2021).

15. Mihailović, B., Popović, V. (2019). Rural tourism in the function of rural areas development in the Republic of Serbia. In V. Bevanda \& S. Štetić (Eds.), 4th International Thematic Monograph Modern Management Tools and Economy of Tourism Sector in Present Era (pp. 251-266). Association of Economists and Managers of the Balkans, Belgrade; Faculty of Tourism and Hospitality, Ohrid.

16. Mihailović, B., Radić-Jean, I. (2019). Resources and potential of agri-food products with added value in Braničevo-Podunavlje region, Economics of Agriculture, Year 66, No. 3, 2019, Balkan Scientific Association of Agrarian Economists, Institute of Agricultural Economics, Belgrade, pp. 669-680.

17. Mihailović, B., Radić-Jean, I., Popović, V., Radosavljević, K., Chroneos Krasavac, B., Bradić-Martinović, A. (2020). Farm Differentiation Strategies and Sustainable Regional Development. Sustainability, Vol. 12, No. 17, 1-18

18. Organisation for Economic Co-operation and Development - OECD (2020), Policy Note COVID-19: SME Policy Responses, https://read.oecdilibrary.org/view/?ref=119_119680-di6h3qgi4x\&title=Covid19_SME_Policy_Responses, (15 January 2021).

19. Perić, G., Dramićanin, S., Milenkovski, A. (2020). Merenje percepcije kvaliteta usluga u ruralnom turizmu Srbije primenom RURALQUAL skale. Bizinfo (Blace), Vol. 11, No. 1, 1-17.

20. Popović, V., Mihailović, B. (2020). Business Models for Urban Farming in and Around Urban Protected Areas: EkoPark Belgrade Case Study. In A. Jean Vasile, J. Subić, A. Grubor \& D. Privitera (Eds.), Handbook of Research on Agricultural Policy, Rural Development, and Entrepreneurship in Contemporary Economies (pp. 89-107). IGI Global, Hershey, PA (USA).

21. Radić-Jean, I., Mihajlović, B. (2019). Istraživanje $i$ analiza poljoprivredno-prehrambenih proizvoda sa dodatom vrednošću i tržišnim potencijalom u regionu Braničevo-Podunavlje [Research and analysis of agro-food products with added value and market potential in the BranicevoDanube region], Regionalna razvojna agencija "Braničevo-Podunavlje", Velika Plana. 
22. Research Center of the Parliament of Montenegro, (2020), Mjere pojedinih zemalja usmjerene na oporavak u sektoru turizma usljed pandemije COVID-19 [Measures of individual countries aimed at recovery in the tourism sector due to the COVID-19 pandemic], 10. maj 2020. godine. https://www.cbcg.me/slike_i_fajlovi/fajlovi/fajlovi_publikacije/ radne_studije/analiza_uticaja_covid-19_na_ekon_i_bank_sistem_cg.pdf, (21 January 2021).

23. Rokvić-Knežić, G., Kalabić, M., Vaško, Ž. (2020). Valorizacija teritorijalnog kapitala u funkciji razvoja ruralnog turizma - studija slučaja opštine Kneževo. Menadžment u hotelijerstvu i turizmu, Vol. 8, No. 2, 35-42.

24. Tomić, S., Leković, K., Eskerod, P., Zedlacher, E. (2020). Profil srpskih i austrijskih potrošača ruralnog turizma. Anali Ekonomskog fakulteta u Subotici, Vol. 56, No. 44, 81-95.

25. Vujko, A., Delić-Jović, M., Zečević-Stanojević, O., Zečević, L., Nedeljković, D. (2020). Gastronomija kao sredstvo upravljanja marketingom i razvoja ruralnih destinacija. Serbian Journal of Engineering Management, Vol. 5, No. 1, 1-13.

26. Vuković, P. (2018). Formiranje i promocija ruralnog turističkog proizvoda u Republici Srbiji. Ekonomika, Vol. 64, No. 4, 81-92.

27. Vuković, P., Mosurović-Ružičić, M. (2020). Potencijali za razvoj turizma hrane u AP Vojvodini u Republici Srbiji. Ekonomika, Vol. 66, No. 1, 77-92.

28. Vuković, P., Popović, V., Arsić, S. (2016). State and Condidtion for Implementing ICT in Rural Tourism in the Republic of Serbia. Proceedings of the 152nd EAAE Seminar Emerging Technologies and the Development of Agriculture, Belgrade; Subotica, 257-275.

29. Yiqing, Z., Lijuan, H. (2015). China's E-commerce Development Path and Mode Innovation of Agricultural Product Based on Business Model Canvas Method. The 14th Wuhan International Conference on E-BusinessInnovation Management and IT Business Value, Wuhan, 9, 560-569.

30. Zenga, Y., Jiab, F., Wanc, L., and Guo, H. (2017). E-commerce in agrifood sector: a systematic literature review. International Food and Agribusiness Management Review, Vol. 20, No. 4, 439-459. 